\title{
Positioning of the Amalgamated Territorial Communities of Ukraine through the Sustainable Development in the Conditions of Military Actions
}

\section{Pozycjonowanie połączonych społeczności terytorialnych Ukrainy poprzez zrównoważony rozwój w warunkach działań wojskowych}

\section{Iryna Budnikevich*, Olena Kolomytseva ${ }^{\star *}$, Yuliia Rohozian ${ }^{\star \star *, \star * \star *}$, Inga Krupenna*, Daria Zablodska ${ }^{\star \star \star}$}

\author{
* Department of Marketing, Innovation and Regional Development, \\ Chernivtsi National University named after Yuri Fedkovich, Ukraine \\ **Department of Economic Cybernetics and Marketing, \\ Cherkasy State Technological University, Ukraine \\ ***Department of Interregional Cooperation Problems, \\ State Institution V.K. Mamutov Institute of Economic and Legal Research \\ of the National Academy of Sciences of Ukraine" \\ ****Address (Corresponding Author): Str. Marii Kapnist 2, 323, Kyiv, Ukraine, 03057 \\ ****E-mail (Corresponding Author): j.s.rohozian@gmail.com \\ ****ORCID: 0000-0001-5325-4213
}

\begin{abstract}
The article summarizes and analyses the scientific approaches to the determination and systematization of the positioning parameters of local level territories. The authors determined and systematized the positioning parameters of the amalgamated territorial communities in Ukraine through the prism of sustainable development elements in the conditions of military operations to form the most effective position of a particular community among other administrative-territorial units of the first level. Based on the results of the analysis of the positioning status in Ukraine, the Ukrainian regions were clustered by the number of ATCs that determined the direction of positioning. It is proved that each of the ATC deserves a worthy positioning of its territory in the eyes of the key stakeholders of its development. However, the communities of precisely Donets`k and Luhans`k regions will do just that, since they continue to receive losses from hostilities unfolding nearby.
\end{abstract}

Key words: positioning, amalgamated territorial communities, sustainable development, analysis, definition and systematization, region, Ukraine, military actions

\section{Streszczenie}

Artykuł analizuje naukowe podejście do określania i systematyzacji parametrów pozycjonowania terytoriów na poziomie lokalnym. Autorzy określili i usystematyzowali parametry pozycjonowania połączonych społeczności terytorialnych na Ukrainie przez pryzmat elementów zrównoważonego rozwoju w warunkach operacji wojskowych. Celem było stworzenie najbardziej efektywnej pozycji określonej społeczności wśród innych jednostek administracyjno-terytorialnych pierwszego poziomu. Na podstawie wyników analizy statusu pozycjonowania na Ukrainie, regiony ukraińskie zostały zgrupowane według liczby ATC, które określiły kierunek pozycjonowania. 
Udowodniono, że każdy ATC zasługuje na godne pozycjonowanie swojego terytorium w oczach kluczowych interesariuszy jego rozwoju. Jednakże społeczności w regionach Doniecka i Ługańska dopiero tego dokonają, ponieważ nadal notują straty wynikające z działań wojennych rozgrywających się w pobliżu.

Słowa kluczowe: pozycjonowanie, połączone społeczności terytorialne, zrównoważony rozwój, analiza, definicja i systematyzacja, region, Ukraina, działania wojskowe

\section{Introduction}

Today, in connection with the final stage of the decentralization reform implementation in Ukraine, the amalgamated territorial communities (hereinafter referred to as ATC) are actively considered by the authorities, scientific and business environment as the first strategic resource for the economic development of the whole country.

The rapid changes of innovative technological character and continuation of active fighting in the east of Ukraine make the administrative-territorial units of the first level not only as a set of natural, material, labour and other resources, but also as an object of image attractiveness. The relevance and importance of applying marketing tools to the ATCs management system is also due to the increased level of competition between communities for investors, business entities, tourists and other key stakeholders in local development.

That is why the development of every sphere of its activity in the near future depends on the competent positioning of the community, therefore it is extremely important to work on creating a stable positive image of the ATC, especially for those communities located near the line of delimitation (in Donetsk and Luhansk which could be reached) increase reputation capital and increase an internal and external investment.

\section{Research methodology}

The purpose of this work is to determine and systematize the parameters of positioning of the ATCs in Ukraine in the conditions of military actions in order to form the most effective position of a particular community among other administrative-territorial units of the first level and to ensure their sustainable development.

This work is based on the generalization of the official methodological information of the ATCs in Ukraine as it has a new decentralization reform for the regions, which will be able to give impetus to the economic development and increase the effectiveness of the ATCs ties.

The methodology of the ATCs positioning is based on the knowledge levels: philosophical level (set of common views and knowledge about phenomena related to the communities positioning); scientific level (understanding of common approaches, principles, positioning forms) and specific methodology (aggregate positioning information of the ATCs in Ukraine).
Also, the research is based on the methods of comparison and analysis (in the context of practical experience in the positioning with the sustainable development elements), groupings and graphical method of information processing (in the context of the ATCs grouping and mapping in the regional context), is based on official normative legal acts of Ukraine, scientific and practical research of leading scientists and economists.

\section{Scientific approaches to the definition and systematization of local positioning parame- ters}

Modern management conditions necessitate application of various tools of marketing influence in the management units of the administrative and territorial structure, among which positioning has a leading role as a process of effective development of local level territories through the formation of their image. For instance, for the first year now, local policy makers in European countries (Denmark, Poland, France) have been actively promoting their area's brands, using such positioning tools as conjoint analysis maps of perception - the method used to examine the preferences of a particular population respondents of the territory).

Undoubtedly, the implementation of positioning process in the system of territorial development requires a deep understanding not only of the needs and expectations of all groups of its stakeholders, but also adherence to the formed values, traditions and features of the territory one, that is, a resident could be both a local investor, an inbound tourist, and a thought leader, emphasizing the need for in-depth processing of all aspects of process in. So, an important step can be a competent determination of the parameters by which the territory can effectively position itself in the domestic market (among other local units of the administrative and territorial structure of the country) and on the external (among the local territories of other states).

Over the last ten years, world and national scientists have been exploring positioning in the context of the territory development, such as: Carpenter (Carpenter, 1989), W. Dow, K. Lim, S. Chenting (Dou, Lim, Chenting, 2010); A. Sunduk (Sunduk, 2012), I. Zabłodska (Zablodska, Hrechana, Zablodska, 2020), O. Kolomytseva (Kolomytseva, 2016), V. Taecharungroj, M. Muthuta (Taecharungroj, Muthuta, Boonchaiyapruek, 2019), W. Andrusiv, L. Simkiv (Andrusiv, Simkiv, Dovgal et al., 2020), S. Shults (Shults, Prytula, Samilo, Maslov, 2019), S. Noskova 
(Rohozian, Noskova, 2017), etc. However, the aspects of determining and systematizing the positioning parameters of local territories have been extremely fragmented, which requires the elimination of this scientific gap.

Polish scientists K. Janiszewska and A. Insch (Janiszewska, Insch, 2012) propose to isolate groups of parameters for positioning local territories (as in Ukraine - communities) according to the target audience (population): concentrated, exclusive, functional and emotional.

Concentrated parameters are aimed at one or more selected target groups, as they should focus on already formed perceptions of the population about the relevant territory (Kotler, 1992). This group includes historical and geographical positioning parameters that are associated with the location of site and unique natural or ethnic characteristics.

Exclusive parameters should be based on unique positions for each target population of the territory (for example, for internal audiences - parameters related to high standards of living and professional development; for external audiences - those that can reflect the investment and tourist attractiveness of the community). The practice of territorial marketing states a high level of exclusive parameters use, as a rule, when applying individual brand strategies for tourism development.

Functional and emotional positioning parameters are diametrically opposite because the former focus on specifics, specific functional features that differentiate a given territory from others, while emotional parameters refer to more abstract emotional benefits, emphasizing how well and uniquely the audience feels. Unlike functional parameters, emotional needs are constantly confirmed and measured, as the subjective attitudes of different target groups of the community may change depending on external factors, such as, for example, a decrease in the level of socio-economic guarantees.

An interesting research also seems to be the approach reflected in the works of I. Bramezza, since it involves the existence of two groups of positioning parameters and the attractiveness of the administrative-territorial unit of the local level (communities, cities, villages and towns):

- structural parameters: high level of infrastructure, provision of administrative and social services, high quality of life and professional growth, etc.;

- functional parameters, i.e. the definition of key functions that can become the center of the territory positioning: recreational, tourist, investment attractive territory, supplier of quality food, location of big business, the center of innovation, important communication (information) center region, cultural. The scientist believes that the combination of the above groups of parameters will help to find a unique way of positioning each territory and justify its attractiveness to residents and external stakeholders (Bramezza, 1996).
The research by I. Bramezza found their continuation in the works of G. Kopychenko, who based on the research of legal and methodological approaches to the analysis of image potential of territorial socioeconomic units, identified and structured key parameters of territory positioning (Table 1).

A similar approach to the definition and systematization of local positioning parameters proposed by A. Zhukova and O. Gayterova, which involves the use of the same factors (parameters) for analysing the development of territorial units at regional and local level, and for their positioning in the internal and external environment (Fig. 1).

Undoubtedly, all of them are shown in fig.1, the positioning parameters in the aggregate form the basis for the attractiveness or unattractiveness of the territory for investment, incl. foreign. Conversely, no investor will invest in an area which is unaware, which proves a direct correlation between the need to correctly position a particular administrative unit and plan its development (Zhukova, Gayterova, 2016). Among the modern domestic scientists who research the issues of determining and systematizing the parameters of territories positioning, it could be distinguished O. Kolomytseva (Kolomytseva, 2016) and S. Pepchuk (Pepchuk, 2016), whose work is mainly focused on the territories of meso level. The authors believe that the main factors that influence the choice of tools for positioning the territory are its parameters that meet the needs of specific consumers, identifying six groups on the basis of physical, functional, economic, aesthetic, symbolic and administrative purpose.

Summarizing the above scientific case researches on the definition and systematization of local positioning parameters, it should be noted that most of the approaches described by the scientists are based on the principles of classic marketing and describe the features of determining the positioning parameters of the territory, in most cases, as a commodity. Undoubtedly, this approach has a logical and rational explanation, but the territory in the form of a specific administrative-territorial unit has a large number of its features of life and development (both internal and external). In addition, it is extremely important to pay attention to determining the parameters of positioning the territory through the prism of the real expectations of the target groups of its consumers (key stakeholders), the existing positioning of competitors relative to those expectations, as well as the competitive and unique advantages of the area itself.

\section{Analysis of positioning results of the amalga- mated territorial communities of Ukraine through the sustainable development in the conditions of military action}

Dynamic information and technological changes of the global environment make one think about the issues of forming a positive image not only of interna- 
Table 1. Positioning of the local level parameters, built by authors according to (Kopychenko, 2014)

\begin{tabular}{|c|c|}
\hline $\begin{array}{l}\text { Groups of } \\
\text { parameters }\end{array}$ & Parameters \\
\hline 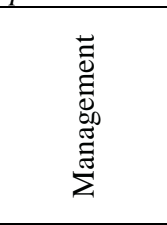 & $\begin{array}{l}\text { the level of transparency and confidence of the residents in the activities of the authorities and local } \\
\text { self-government; } \\
\text { quality and accessibility of administrative services for the population of the territory; } \\
\text { consistency and effectiveness of implementation of decisions by local authorities; } \\
\text { the level of public-private partnership development at the local level; } \\
\text { effective budgetary policy. }\end{array}$ \\
\hline 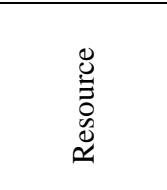 & $\begin{array}{l}\text { the presence of significant historical and cultural heritage; } \\
\text { the level of creative potential of the population and the level of entrepreneurship culture; } \\
\text { skill level of the workforce; } \\
\text { availability of diversified sources of local budget revenues and private investment; } \\
\text { favourable geographical location of the territory and its natural and climatic base. }\end{array}$ \\
\hline 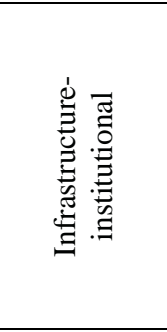 & $\begin{array}{l}\text { availability of engineering infrastructure (energy efficient systems of ensuring the vital activity of the } \\
\text { administrative-territorial unit); } \\
\text { availability of innovative and technological infrastructure (availability of modern communication } \\
\text { network, level of innovation and technological provision of scientific and higher education institu- } \\
\text { tions); } \\
\text { availability of social infrastructure (availability of modernized institutions at all levels of education, } \\
\text { medical facilities with high-tech equipment, the level of development and accessibility of cultural } \\
\text { institutions, specialized places of mass rest, etc.); } \\
\text { current state and level of transport development objects, legal and institutional infrastructure. }\end{array}$ \\
\hline $\begin{array}{l}\bar{\pi} \\
\text {. } \\
\text { क }\end{array}$ & $\begin{array}{l}\text { the level of life safety in the area; } \\
\text { demographic trends; } \\
\text { quality of life's population (quality of education, health care, cultural development, recreation, hous- } \\
\text { ing, etc.); } \\
\text { favourable environmental status and attractiveness of the environment. }\end{array}$ \\
\hline
\end{tabular}

\section{Economic}

- production (labor, capital, land, entrepreneurial abilities);

4. Organizational

- innovative (scientific and technical potential).

2. Administrative

- quality of local management;

- openness and willingness of the authorities to dialogue with society.

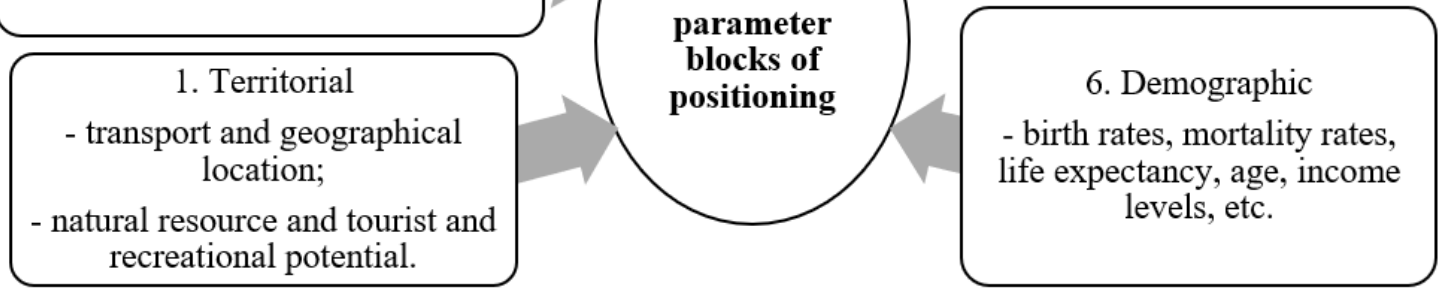

Figure. 1. Classification of basic parameters of the local level territory positioning, built by authors according to (Zhukova, Gayterova, 2016)

tional and national level subjects, but also of local ones. Practice proves that in recent years the European administrative-territorial units (communities and cities, villages, settlements) have been actively implementing the provisions of the developed marketing strategies in order to create a positive image of the territory.

Ukrainian cities also follow the current trends and not for the first year actively implement the measures of their marketing and communication strategies, among which Vinnytsia, Melitopol, Yaremche, Kolomyia, Enerhodar, Ivano-Frankivs`k, Kryvyi Rih and Berdyans`k (Territory branding and marketing. What is the secret of the most successful cities in Ukraine? 2019). Despite the existence of a positive example of larger-sized neighbours (cities), the newly created first-level administrative-territorial units in Ukraine - the ATC are just beginning their path to shaping their image.

Undoubtedly, the image of the community can be perceived both positively and negatively, but in most cases the selection of absolutely extreme positions is impossible due to the large set of quantitative and qualitative characteristics that can be interpreted as 
gains and miscalculations. Awareness of ATC's residents, business representatives, and other internal and external stakeholders in the presence of such aggregate characteristics will shape the community's reputation. As S. Pepchuk points out in dissertation, if the territory has a weakly expressed positive reputation, it requires not just active development of positive characteristics, but an effective positioning strategy with a set of measures to consolidate positive characteristics and the ability to counteract negative ones. The purpose of such a strategy is to develop a sustainable positive image, which in turn will open a new round of the area development with a strong positive reputation. That is, a sustainable positive image can be converted into reputational capital and direct investment. The starting point for the formation of a positive image is an image of the territory, based on theory of images (vision theory) and is an individually perceived phenomenon that acts as a product of human activity and is a complex result of environmental reality transformation. On the one hand, the image of the terrain is both a product and the result of key values vision (reputation), on the other - is the basis of change strategy, the prototype of the territory in 5-10 years (image) (Pepchuk, 2016).

In this context, it is necessary to emphasize the importance and necessity of forming a positive image of each territory in Ukraine, especially ATC located in Donetsk and Luhansk regions and with which other local and economic entities are in contact with the purpose of consolidating efforts (including financial) to resolve common problems associated with hostilities.

It is obvious that the most attractive territory for internal and external investments is emerging, possessing unique resources and opportunities and profitable to give to others, so it is important to understand the current state of communities positioning in Ukraine in order to further plan the development of these territories.

It is important to add one more to the above arguments - the regulatory one. The priority direction of Ukraine's foreign policy is the process of its integration into the European Union, in which our country is obliged to harmonize its legislative base with the European Union, including in the context of implementing sustainable development principles. The provisions of the current Sustainable Development Strategy Ukraine 2020 provide for the implementation of the program to promote Ukraine in the world and promote its interests in the global information space as one of its top priorities. Thus, in accordance with the strategy throughout 2020, our country focuses on creating a positive image of the whole country and its administrative and territorial elements, forming and promoting brand messaging: Ukraine is a country of freedom and dignity; Ukraine is a reforming country despite its challenges; Ukraine is a hub for investment; Ukraine is a country of high technology and innovation; Ukraine is a country attractive for tourism; Ukraine is a country with significant cultural and historical traditions (Administration of the President of Ukraine, 2015). These data will find their mandatory continuation in the 2030 Sustainable Development Strategy of Ukraine, developed by UNDP and Global Environment Fund representatives in within the framework of the project Integration of the provisions of the Rio Conventions into the national policy of Ukraine and was taken as the basis. Thus, the provisions of the project stipulate the need to align regional, urban and territorial development strategies with the Sustainable Development Strategy of Ukraine in order to ensure a harmonious integration of national, regional and local interests (within the operational objective 4.3. To make the cities and settlements inclusive, safe and sustainable) (Representation of the United Nations Development Program in Ukraine, 2017). Also, the rules of the Methodological Recommendations for the Formation and Implementation of the Forecasting and Programming Documents of the Socio-Economic Development of the Amalgamated Territorial Communities (Ministry of Regional Development, Construction and Housing and Communal Services of Ukraine, 2016) stipulate the need to formulate a Development Plan of each community, taking into account the principle of sustainable development.

It is important to note that ATCs will not be able to implement all 17 global and national Sustainable Development Goals into their core documents - Development Strategies given the fact that some of the goals become more relevant at the national level. In addition, the capacity of local and local governments to implement the sustainable development goals is limited in accordance with the statutory mandate. However, the specific priorities for sustainable development of the community are determined on the basis of an analysis of current problems within the classical triad of components: economic, social, environmental, which are characteristic of each administrative and territorial unit of the first level.

Undoubtedly, the above-mentioned priorities for the current sustainable development strategy implementation and the public statements of the newly created government representatives (in particular, the Ministry of Foreign Affairs of Ukraine and the Ministry of Communities and Territories of Ukraine) also emphasize the urgent need to develop a positive image at the ATC level in connection with the implementation of reform components of decentralization power. However, due to the lack of analytical research in Ukraine related to the rationale for the mechanisms and steps for the formation of their positive image, it is advisable to focus on defining and organizing the basic parameters by which each community will be able to effectively position itself in both the internal and external environment. Given the fact that positioning is the development and cre- 
Table 2. Determination and systematization of the ATC's parameters of Ukraine through the sustainable development components, developed by the authors

\begin{tabular}{|c|l|}
\hline $\begin{array}{c}\text { Sustainable development } \\
\text { components }\end{array}$ & \multicolumn{1}{c|}{ Parameters of ATC's positioning } \\
\hline \multirow{2}{*}{ 1. Economic } & financial and budgetary self-sufficiency \\
\cline { 2 - 2 } & industrial potential \\
\cline { 2 - 2 } & engineering and transport infrastructure \\
\hline \multirow{2}{*}{ 2. Social } & social infrastructure for providing services to the population \\
\cline { 2 - 2 } & demographic community development \\
\hline \multirow{2}{*}{ 3. Ecologic } & natural and geographical conditions \\
\cline { 2 - 2 } & historical and cultural heritage, ecological and tourist-recreational potential \\
\hline
\end{tabular}

ation of the territory image so that it occupies a decent place in the minds of stakeholders, it is obvious that the positioning parameters should be clear to all stakeholders and, at the same time, providing opportunities for a particular community to become better or unique in any field of life. Taking into account the fact that each ATC in Ukraine plans its life in the context of sustainable development, it is logical to propose the most important parameters for positioning communities in terms of economic, social and environmental components (Table 2).

\subsection{Economic dimension}

Given that the economic component of the sustainable development tradition involves the optimal use of limited resources (natural, material, labour, etc.), while using environmentally friendly technologies and focusing on increasing the level of production and processing of raw materials, the creation of environmentally friendly products, minimization, recycling waste, it is proposed to allocate in this block three parameters that most fully and accurately cover the level of economic status and community development:

1. Financial and budgetary self-sufficiency. This parameter may provide an analysis of such economic indicators as:

Local Budget Transparency Index (Holyns`ka, Matvienko, 2017);

indicators that characterize the implementation of ATC budgets (according to official statistics presented on the websites of the communities, the Ministry of Finance of Ukraine, the State Treasury Service of Ukraine, the State Statistics Service of Ukraine, and data on the openbudget.gov.ua web portal):

per capita income (the ratio of the volume of general fund revenue without transfers to the number of residents of the relevant ATC);

the level of budget subsidy (the ratio of the amount of base or reverse subsidy to the amount of income of the general fund of the ATC, excluding subsidies from the state budget);

the share of expenditures for the maintenance of management apparatus in the financial resources of the ATC (the percentage of the expenditures for the maintenance of the management apparatus of local self-government bodies in the amount of general fund revenues, without transfers from the state budget);

share of wages in general fund expenditures (percentage of expenditures made from the general budget on wages plus payments to the general budget expenditures excluding transfers transferred from the ATC budget to other budgets).

The above indicators are already widely used by ULEAD experts from Europe and SKL International (as part of the Ministry of Finance's Monitoring Unit of the Ministry of Regional Development Reforms until August 2019) in the preparation of the Indicators of the implementation of the ATCs budgets, 2019) of the basic tools for determining the directions of effective positioning of territorial communities (Decentralization power in Ukraine, 2019).

2. Industrial potential of the territory. This parameter can be a major source of community information for investors, as a territory with strong industrial and, at the same time, scientific and innovation potential looks attractive to investors. The following statistics can be used to reveal this parameter:

availability of budget-forming enterprises and powerful enterprises of the real economy in the community;

availability and financing of small and medium business development programs implemented on the territory of the ATC;

the number of employees employed by business entities located in the community;

the volume of sales (goods, services) by business entities located in the community.

3. System of engineering and transport infrastructure. This parameter is revealed through the analysis of indicators related to the number and condition of engineering and transport infrastructure objects, in particular the number of projects related to the construction of new facilities, reconstruction, overhaul of streets, transport routes (including road, railways), bridges, communal property crossings; development of lighting, heating, telephony, internet coverage, water supply and more.

\subsection{Social dimension}

The social component of sustainable development is viewed through the prism of principles such as meeting basic human needs in clean air and water, healthy food, affordable provision of quality prevention and 
care, treatment for all members of the community, safe and healthy housing, accessible for all, equal access to quality education services etc. Therefore, in order to cover the most important spheres of activity that are affected by this component, it is recommended to identify two basic parameters for positioning the territorial community:

1. System of social infrastructure and services for the population. This parameter can be considered through the statistical indicators of quantity and availability of resource basil, education, medicine, culture, public services and the quality of their provision to the population (provision of general practitioners by family doctors per 1000 population; availability of seats and average occupancy of preschool groups educational institution, secondary school and higher education institution of the united territorial community, share of new or reconstructed housing in the housing stock, number of cultural and sports facilities, located in the community, etc.).

2. Trends on the demographic development of the community can be considered through the prism of the following statistics:

- increase of the population of permanent population aged 16-59;

- natural population growth;

- reduction of demographic burden per 1000 persons of working age;

- reduction of the total rate of the rural population dropout (per 1000 people of the existing rural population);

- reducing the number of people in need of social support, etc. (Ministry of Regional Development, Construction and Housing and Communal Services of Ukraine, 2016).

\subsection{Ecological dimension}

The ecological component of the sustainable development has traditionally been revealed by ensuring the integrity of biological and physical natural systems, preserving the ability of ecosystems to self-renew and dynamically adapt, preventing degradation of natural resources, pollution and loss of biological diversity. In order to comply with these principles, it is proposed to consider the environmental aspect of positioning through two parameters:

1. Natural and geographical conditions. Familiarity with each ATC begins with the consideration and analysis of the starting conditions of its life, which, to a large extent, depends on the further effective territory development. As with the preparation of the Community Development Strategy, the following characteristics should be noted:

- the ATC creation date, the number of communities that are part of it (urban, rural, urban), within which region of Ukraine it is located (central, western, eastern, southern or northern);

- the total area of the ATC, the location of its administrative center;
- the zoning, conditions of climate, terrain, landscape, paleogeography (available minerals and deposits), types of community soils;

- the presence and extent of reservoirs in the community (rivers, lakes, sea, reservoirs, waterfalls, etc.);

- the presence of landscape and nature conservation areas in the ATC (reserves, reserves, tracts, beams, pastures, virgin hollows, etc.).

2. Historical and cultural heritage, ecological and tourist-recreational potential. This parameter is one of the main components of the environmental component of sustainable community development, because it is through it that we can find those unique characteristics or objects that only one particular community possesses. Of course, almost every territory in Ukraine, with its several hundred years of history, has preserved in one way or another tangible or intangible monuments of history, archaeology, art, unique traditions, customs (including religious), ancient recipes of food production or objects life, documents proving the involvement of a prominent historical figure in the community - each of these examples can be a cornerstone for the effective positioning of an ATC and the formation of its positive image.

In addition, it is no secret that Ukrainian communities, unfortunately, have unfulfilled tourism potential against the backdrop of the great opportunities available, as more and more popular tourist attractions (cities such as Lviv, Kamenets-Podilskyi, Odessa) are gaining more and more popularity eco-tourism, when a resident of a large and suffocating city seeks to stay in an environmentally friendly place with unique traditions and original dishes. In addition, significant environmental and tourism-recreational potential can be a good source of income for communities, so this parameter can be considered by the following indicators:

- volume of income from tourism activities;

- number of tourists and sightseers for a certain period;

- availability of sanatorium and resort establishments, number of places for accommodation;

- area of natural recreational and tourist resources of the community;

- number of cultural, historical and architectural monuments;

- number of tourist activity subjects;

- developed system of tourist infrastructure. Each of the identified community positioning parameters can become the quintessence of this process and create a positive image of the ATC both internally and externally. However, the concept of sustainable development and the practical experience of strategic planning for the development of territorial communities prove the need to combine the parame- 
ters of economic, social and environmental components as interdependent and complementary elements of life. For instance, creating new or upgrading existing community infrastructure will help improve access to services and markets without harming the environment; preserving and protecting the unique historical and cultural heritage will contribute not only to the development of tourist potential, but also to the improvement and strengthening of social manifestations of cultural diversity, values, customs and traditions.

\subsection{Current positioning of the Ukraine}

Confirmation of these arguments is the results of the current positioning analysis of the Ukrainian ATCs in the regional context. Thus, as of 01.30.2020, out of 981 ATCs available, only 50 have determined their positioning, of which 20 urban communities are, 10 are rural and 20 are village territories. Some of the above communities not only outlined their positioning in development strategies, but also formed marketing and / or communication strategies for the development of their territories. Thus, Vasylkivka (Dnipropetrovs`k region), Verkhnyans'ka (IvanoFrankivs`k region), Smolinska (Kirovohrad region), Bashtanska, Mostivska, Alexandrivska (Mykolaiv region), Terebovlyans`ka (Ternopil region) and Starosaltivs `ka communities (Kharkiv region) have Communication Strategies for their development, and Kolomyis`ka (Ivano-Frankivs`k region) - Marketing Strategy. The fact that communities pay attention to the formation of their image is undoubtedly a positive phenomenon, but all the communication strategies of the above communities are written in a kind of copier - with the same positioning for each of them, which does not contribute to creating their positive and unique image as they will be associated with all target consumer groups equally, without highlighting any unique characteristics that have been etched in memory for a long time. With regard to the marketing strategy for the development of the Kolomyis `ka ATC, the essence of its positioning is set out too broadly, which makes it impossible to associate this area with something specific.

In order to determine asymmetry in the context of community positioning analysis, 24 regions of Ukraine were investigated by clustering them by interval quantitative trait, which in this case is the proportion of the ATCs of a region that has already formed the direction of positioning its territory to the total number of the ATCs located in that region. In addition, for clustering it is necessary to determine the optimal number of clusters for the most efficient display of the total population of objects (in this case, region using the Sturges' formula):

$$
\begin{gathered}
\mathrm{n}=1+3,322 \operatorname{lgN}=1+3,322 \lg 24=1+ \\
3,322(1,3802)=5,58436
\end{gathered}
$$

where $n$ is the number of groups (clusters); $N$ is the total number of units.
According to the calculation, the optimal number of clusters out is a total of 24 objects is 5 , so the 24 Ukrainian regions will be divided into 5 groups for analysis.

The results of the community positioning analysis revealed the presence of regions whose positioning status indicator is very different from other results, so it is logical to attribute such regions to the respective separated clusters. Thus, the 3 regions of Ukraine do not have any ATCs that would form the direction of positioning their territory, so they form a separate cluster where the quantitative trait is zero. There are also two regions of Ukraine, where the proportion of the ATCs with a certain direction of positioning is extremely high, which is very different from other obtained results, so they will also form a separate cluster with the highest values of a given indicator. The other three clusters will contain regions by interval quantification, and given that the results obtained are too wide, the interval will range from $0.01 \%$ to $14.98 \%$, and its step will be 4.98 respectively. By consistently adding an interval step to the bottom level of each set of objects, groupings are created at regular intervals, except for the first and last clusters mentioned above.

Thus, the cluster with the highest proportion of the ATCs that already have directions of their positioning to the total number of the ATCs in the region will have a value of $\geq 14.99 \%$ and the name Professionals; the second cluster Activists, the third Enthusiasts and the fourth Beginners will be grouped in 4,98 intervals and will be respectively $10,00 \% \geq 14,98 \%$, $5,00 \% \geq 9,98 \%$ and $0,01 \% \geq 4.99 \%$. The last cluster with a zero value of the analysed indicator will be called Inert, since there is no activity of ATC regarding positioning in the territories of these regions (Fig. 2).

The results obtained in this article indicate the asymmetry of community positioning process in Ukraine: most of them are just beginning to think about the need to create a positive image of their territory and are trying to take the first steps to form positioning directions that, in most cases, do not correlate with operations at all community development, or described in very fragmented and general terms. The most experienced regions in the context of the ATC positioning were eastern regions bordering on active military action territories - Donets` $k$ and Kharkiv regions where respectively 4 and 7 communities are actively exercise their task to create unique and bright image of the area. The success of the Kharkiv region is due, first of all, to the fact that its communities were among the first to start a voluntary association, so now, with an already updated development strategy for the period up to 2027, they are already making far-sighted plans for with the help of international donors U-Lead representatives, UNDP and others, including the process of forming a positive image of the territory. 


\begin{tabular}{|c|c|c|c|c|}
\hline \multicolumn{5}{|c|}{ Clusters types by ATC's activity positioning } \\
\hline $\begin{array}{c}\text { Cluster } 1 \\
\text { Professionals }\end{array}$ & $\begin{array}{l}\text { Cluster } 2 \\
\text { Activists }\end{array}$ & $\begin{array}{c}\text { Cluster } 3 \\
\text { Enthusiasts }\end{array}$ & $\begin{array}{c}\text { Cluster } 4 \\
\text { Beginners }\end{array}$ & $\begin{array}{c}\text { Cluster } 5 \\
\text { Inert }\end{array}$ \\
\hline ATCpos $\geq 14,99 \%$ & ATCpos $10,00 \% \geq 14,98 \%$ & ATCpos $5,00 \% \geq 9,98 \%$ & ATCpos $0,01 \% \geq 4,99 \%$ & ATCpos $=0$ \\
\hline Donets`k $(30.77 \%)$ & Sumy $(13.16 \%)$ & Mykolaiv (9.52\%) & Rivne $(4.44 \%)$ & Zakarpattia $(0 \%)$ \\
\hline Kharkiv $(30.43 \%)$ & Chernivtsi (10.81\%) & Lviv $(7.32 \%)$ & Dnepropetrovs`k $(4.28 \%)$ & Kyiv $(0 \%)$ \\
\hline Total regions: 2 & Total regions: 2 & Vinnytsia $(6.52 \%)$ & Chernihiv $(4.00 \%)$ & Poltava $(0 \%)$ \\
\hline & & Luhans`k (5.55\%) & Kirovohrad $(3.70 \%)$ & Total regions: 3 \\
\hline & & Ivano-Frankivs`k (5.13\%) & Ternopil (3.70\%) & \\
\hline & & Total regions: 5 & Kherson $(3.03 \%)$ & \\
\hline & & & Odessa $(2.70 \%)$ & \\
\hline & & & Khmelnits`ky (1.96\%) & \\
\hline & & & Volyn $(1.85 \%)$ & \\
\hline & & & Zhytomyr (1.78\%) & \\
\hline & & & Zaporizhzhia (1.78\%) & \\
\hline & & & Cherkasy $(1.75 \%)$ & \\
\hline & & & Total regions: 12 & \\
\hline
\end{tabular}

Figure 2. Clustering of Ukrainian regions by the number of ATCs, determined by the direction of positioning, developed by the authors

Among the activists are Sumy and Chernivtsi regions, where respectively 5 from 38 ATCs and 4 from 37 ATCs have already decided on the directions of positioning their territories. The results of the analysis of the current positioning state that all communities of these areas focus on the parameters of the ecological component of sustainable development, which is due to the presence of a unique historical and cultural heritage of the ATC data and, as a consequence, the development of ecological and tourist-recreational potential.

Five regions of Ukraine are assigned to the cluster Enthusiasts in connection with their ATC efforts to fully cover the areas of their positioning, forming a symbiosis of economic, social and environmental parameters, which prevents key stakeholders of this process to form a specific image of a community.

The largest cluster is the set of regions called Beginners, which includes 12 regions of Ukraine, the ATCs have just begun to implement ideas and areas of their positioning, which are closely linked to the slowest processes of the decentralization reform implementation components and, accordingly, the least experienced recently amalgamated communities.

The results of regions currently occupied temporarily in connection with the military actions in the east - Donets` $k$ and Luhans`k regions should be emphasized separately. Donets`k region occupies the first place in the cluster of professionals, where 4 from of 13 ATCs (30.77\% of the total ATCs in the region) are already actively working on forming their positive image. Andriyivs`ka, Lymans`ka, Oleksandrivs`ka and Soledars`ka ATCs have quite well-formed directions of their positioning, which are based on the parameters of economic and environmental components of sustainable development (significant industrial potential, developed system of engineering-transport infrastructure, fa- vourable natural and geographical conditions; significant ecological, tourism and recreational potential). Due to the recent merger of two ATCs that have joined the 11 existing ones in the area, their location, not far from the demarcation zone, makes adjustments to life planning, so it is not possible to observe a large development thesis at present high concentration of heavy industries as it was before. Of the represented communities of Donetsk region only Soledars 'ka ATC is oriented to the development of its territory as socially successful for business activities, including budget-forming enterprises of industrial and agrarian sectors of the national economy, others plan to create an image of their locality through the existing natural, geographical and infrastructural preconditions, which have formed several decades ago.

Another level of the positioning process development is observed in the territory of Luhansk region: from 18 ATCs, only one Belovods`ka ATC (which makes up $5.55 \%$ of the total ATC in the region) deals with the positioning of its territory, so this area is classified as a cluster of enthusiasts. The historically formed heritage of the Belovods 'ka region found a competent expression in the positioning of this community as the capital of equestrian factories of Ukraine, which at one time was considered to be the Imperial Stationery Office, and now the Belovods ka region is the only one in Ukraine and Western Europe, where there are four horse factories of the eighteenth century (Vorontsov, 2019).

\section{Conclusions}

The analysis of theoretical achievements of territorial marketing made it possible to ascertain the presence of more than a dozen scientific researches of both foreign 
and domestic scientists, who are devoted to the problem of determining and systematizing the parameters of positioning local territories. Research in the case studies on this topic has shown that most of the approaches described by the scientists are based on the principles of classical marketing and describe the features of determining the parameters of positioning the territory as a commodity, which significantly narrows the ability of the territory to find their unique characteristics and present them to the world format, because it complicates the process of identifying the real expectations of the target consumer groups, the existing positioning of competitors relative to these expectations, as well as competitors and their unique advantages of the area.

In view of the continuation of military actions, the communities located on the territory under the control of the Ukrainian authorities are concerned with other, more pressing issues of their socio-economic development, forgetting that the formation of a positive image will help attract internal and external investment in communities, and as a consequence, will play a hand in solving the current problems of ATC and the region faster.

Undoubtedly, each ATC deserves a decent positioning of its territory in the eyes of key stakeholders in its development, but the communities of Donets $k$ and Luhans`k regions need it the most, as they continue to receive damage from the unfolding military actions. Most of all this concerns the forced positioning of these territories exclusively as adjacent to the conflict zone, which makes it impossible for the socio-economic development of the area due to the investment neglect of these areas as unreliable and unpromising. Thus, the communities of Donets ` $k$ and Luhans ` $k$ regions should think very carefully about each of the possible areas of their positioning in order to create a positive image and image, which is important for expanding and improving the dialogue between target groups of consumers, as well as informing the public not only about the military conflict, but also about with the help of well-selected news, where the key to success is the community's success stories.

\section{References}

1. CARPENTER G, 1989. Perceptual position and competitive brand strategy in a two-dimensional, 2-Brand market, in: Management Science, 35, p. 1029-1044.

2. DOU W., LIM K., CHENTING S., 2010. Brand positioning strategy using search marketing, in: Mis Quarterly, 34(2), p. 261-279.

3. SUNDUK A.M., 2012. Positioning of Transcarpathian region within the system 'State - Global dimension', in : Actual Problems of Economics, 128, p. 211-218.

4. ZABLODSKA I., HRECHANA S., ZABLODSKA D., 2020. The Identification of the Luhansk Region and the Region Act's According to the Qualification of Their Sustainable Development in the Conditions of the Joint Forces Operation, in: Problemy Ekorozwoju/ Problems of Sustainable Development, 15(1), p. 197-210.

5. KOLOMYTSEVA O., 2016. Positioning of regions of Ukraine in competitive environment, in: Proceedings of the 1st International Conference Contemporary Issues in Theory and Practice of Management, p. 203-209.

6. ANDRUSIV U., SIMKIV L., DOVGAL O. et al., 2020. Analysis of economic development of Ukraine regions based on taxonomy method, in: Management Science Letters, 10(3), p. 515-522.

7. SHULTS S., PRYTULA H., SAMILO A., MASLOV V., 2019. The magnitude and nature of the shadow economy in Ukrainian border regions, in: Financial and credit activities: problems of theory and practice, $\mathrm{p}$. 394-401.

8. TAECHARUNGROJ V., MUTHUTA M., BOONCHAIYAPRUEK P., 2019. Sustainability as a place brand position: a resident-centric analysis of the ten towns in the vicinity of Bangkok, in: Place Branding and Public Diplomacy, 15(4), p. 210-228.

9. ROHOZIAN YU., NOSKOVA S., 2017. Interregional cooperation as a prerequisite for the economic development of amalgamated territorial communities in Ukraine, in: Baltic Journal of Economic Studies, 3(5), p. 383-390.

10. JANISZEWSKA K., INSCH A., 2012. The Strategic Importance of Brand Positioning in the Place Brand Concept - Elements, Structure and Application of the Positioning Statement, in: Journal of International Studies, 5(1), p. 9-19.

11. KOTLER P., 1992. Marketing's New Paradigm: What's Really happening Out There. in: Planning Review, 20(5), p. 50-52.

12. BRAMEZZA I., 1996. The competitiveness of the European city and the role of urban management in improving the city's performance. Tinbergen Institute, Rotterdam.

13. KOPYCHENKO G., 2014. Municipal Competitiveness Management. Moscow.

14. ZHUKOVA A., GAYTEROVA O., 2016. Foreign investment as a factor in the development of the regional economy, in: XI International Conference 'Russian Regions in the Focus of Changes', p. 263-271.

15. PEPCHUK S., 2016. Positioning of the region in the system of competitive relations. Cherkasy State Technological University, Cherkasy.

16. TERRITORY BRANDING AND MARKETING. WHAT IS THE SECRET OF THE MOST SUCCESSFUL CITIES IN UKRAINE? 2019. Partnership for Urban Development International Technical Assistance Project, Federation of Canadian Municipalities, http:// pleddg.org.ua/wp-content/uploads/2019/09/Case_Study _PLEDDG_Regional_BrandingMarketing_2019.pdf (05.03.2020).

17. ADMINISTRATION OF THE PRESIDENT OF UKRAINE, 2015. On the Sustainable Development Strategy 'Ukraine 2020', https://zakon.rada.gov.ua/ laws/show/5/2015 (10.03.2020).

18. REPRESENTATION OF THE UNITED NATIONS DEVELOPMENT PROGRAM IN UKRAINE, 2017. The Draft of Sustainable Development Strategy of Ukraine until 2030, https://www.undp.org/content/ dam/ukraine/docs/SDGreports/UNDP_Strategy_v06optimized.pdf (10.03.2020).

19. MINISTRY OF REGIONAL DEVELOPMENT, CONSTRUCTION AND HOUSING AND COMMUNAL SERVICES OF UKRAINE, 2016. Guidelines for the formation and implementation of forecast and program documents of socio-economic development of the amalgamated territorial communities, http://zakon.rada gov. ua/rada/show/v0075858-16_(10.03.2020).

20. HOLYNS KA O., MATVIENKO A., 2017. Methodology for assessing transparency of local budgets, Eastern Europe Foundation, Kyiv.

21. DECENTRALIZATION POWER IN UKRAINE, 2019. Indicators of the implementation of the regional budgets for the 9 months of 2019, https://decentralization.gov.ua/ news/11926 (16.03.2020).

22. VORONTSOV P., 2019. Despite the military actions, Luhansk region seeks to develop the tourism sphere of the economy, http://www.golos.com.ua/article/317864 (16.03.2020). 